\title{
Modern and fossil non-pollen palynomorphs from the Basque mountains (western Pyrenees, France): the use of coprophilous fungi to reconstruct pastoral activity
}

\author{
Carole Cugny $\cdot$ Florence Mazier $\cdot$ Didier Galop
}

Received: 31 January 2009/Accepted: 4 February 2010/Published online: 16 April 2010

(C) Springer-Verlag 2010

\begin{abstract}
This paper presents results from a modern dataset of non-pollen palynomorphs and its application to a ca. 2,000 year peat record from the same area in the western Pyrenees (Basque Country, France). The modern dataset is composed of 35 surface samples (moss polsters) from a mountainous pasture-woodland landscape. Airborne fungal spores (ascospores and conidia), found dominant in the dataset, are linked to the degree of landscape openness and grazing pressure. The complete spectrum of 13 selected spore-types of dung-related Ascomycetes is positively linked with grazing pressure. However, different dung affinities between the spore-types have been identified. These are types clearly related to high grazing pressure and types with no or unclear dung indicative value. The modern dataset is used to aid interpretation of the local fossil pollen record as an independent 'proxy' to assess past pastoral dynamics. This study confirms the utility of modern nonpollen palynomorphs from terrestrial ecosystems in the reconstruction of historical local pastoral activities but also shows their limitation. It may be necessary to extend such study to wetland ecosystems and to investigate the spatial dimension of some fungal spores.
\end{abstract}

Communicated by J.N. Haas.

C. Cugny $(\bowtie) \cdot$ F. Mazier $\cdot$ D. Galop

Laboratoire de Géographie de l'Environnement (GEODE),

UMR 5602 CNRS, Université Toulouse-Le Mirail,

5 allées A. Machado, 31058 Toulouse Cedex, France

e-mail: cugny@univ-tlse2.fr

F. Mazier

GeoBiosphere Science Centre, Lund University,

Sölvegatan 12, 22362 Lund, Sweden
Keywords Non-pollen palynomorphs (NPPs) ·

Modern and fossil NPPs - Coprophilous Ascomycetes .

Grazing activities $\cdot$ Pyrenees

\section{Introduction}

Interdisciplinary research programs including palaeoecological, archaeological and historical investigations have been carried out during the last decade in the Iraty massif (western Pyrenees, France). These programs aim at reconstructing Holocene environmental changes linked to human activities, particularly pastoral activities. In this respect, non-pollen palynomorphs (NPPs) have been used in addition to pollen analysis of peat sediments with special attention paid to coprophilous fungi.

Fungal remains, most often their spores, are an important part of the 'non-pollen' information in peat deposits (van Geel and Aptroot 2006). They are potential indicators of specific ecological (e.g. wetness) and substrate (e.g. specific host plants, decaying organic matter including dung) conditions (e.g. van Geel 2001; Mighall et al. 2006; van Geel and Aptroot 2006; Yeloff et al. 2007). Fossil ascospores of dung-related fungi can be used to assess the presence of past fauna, in particular herbivores (wild or livestock) (e.g. van Geel et al. 1983, 2003; Davis 1987; Ralska-Jasiewisczowa and van Geel 1992; Hausmann et al. 2002; Bos et al. 2005; Davis and Shafer 2006; Mazier et al. 2009).

However, NPPs are still overlooked in the study of palynological assemblages and their indicative value is still debated. This is partly due to the lack of accuracy of identification of the remains ('types') that limit the possibilities for linking fossil data with the corresponding living organisms' ecology (van Geel and Aptroot 2006), 
whenever this latter is known. Discrepancies between modern and fossil material are the result of alterations that occur in the sediment and during palynological preparations (Prager et al. 2006). The selective preservation of taxa and material is also responsible for the relatively low diversity of fossil assemblages compared to modern diversity (van Geel and Aptroot 2006; Yeloff et al. 2007); e.g., for fungi, ascospores and conidia are overrepresented.

The construction of modern NPP datasets is one of the ways in which these issues can be addressed. Several studies have attempted to link current environments and land-uses, or substrates, to modern NPP assemblages from mosses, soils, litter, or even dead wood or water (Mulder and Janssen 1999; Mulder et al. 2003; Blackford and Innes 2006; Graf and Chmura 2006; Prager et al. 2006; Yeloff et al. 2007). Despite these approaches, which differ in their methodological aspects (spatial resolution, sampling methods, substrates used for the collection of NPPs, environmental parameters taken into account, etc.), they have provided valuable information on NPP indicative values for palaeoecologists. For instance, Mulder et al. (2003) demonstrated the significance for palynological purposes of fungal remains extracted from soils defined as litter-, dungor wood-related fungi and ericoid mycorrhizal fungi. Modern approaches also permitted Blackford and Innes (2006) and Graf and Chmura (2006) to show that coprophilous fungi ascospores (Sporormiella, Cercophora, Sordaria, Tripterospora, Cercophora, Chaetomium, Podospora, Type 55B) are local dung indicators.

Like many of the organisms they originate from, most NPPs are considered to be cosmopolitan. However, most of the current knowledge on NPPs has been acquired from fossil records from northern and/or eastern Europe (van Geel and Aptroot 2006; Yeloff et al. 2007). Despite the importance of these contributions, this knowledge of NPPs (types and ecology) is not necessarily applicable in other biogeographical contexts, such as mountainous regions of southern Europe. Therefore, it is worth developing models of the modern NPPs/environment relationship in the Pyrenees if fossil NPP sequences from the same area are to be interpreted. Mazier et al. (2006) collected moss polster samples from various vegetation communities from within a small topogenic peat bog basin to investigate the pollen/vegetation/land-use relationships. These samples were employed for the study of modern NPPs. Fossil NPPs were then analysed from the peat bog, which had previously been cored for pollen analysis (Mazier et al. 2009).

The main aims of this paper are:

(1) To asses the environmental indicative value of modern NPPs in a mountainous area of the western Pyrenees, where they have seldom been studied.
(2) To focus on the relationships between dung-related Ascomycetes and current grazing activities.

(3) To apply these results to the interpretation of a fossil record from the same area, to compare them with previous pollen data and discuss their accuracy.

\section{Materials and methods}

\section{Modern dataset}

The modern analogue dataset includes 35 sites $\left(100 \mathrm{~m}^{2}\right)$ used for vegetation inventories, the collection of land-use variables and NPP analysis. They are distributed in the woodland pastures of the Iraty mountains (Basque Country, western Pyrenees, France; Fig. 1) between 700 and 1,500 $\mathrm{m}$ a.s.l. Current land-use practices are based on traditional transhumance from the valleys to the summer pastures. Livestock is mainly composed of sheep, some horses and cows. Pigs are confined to the surroundings of the pastoral huts. Wild herbivores commonly occurring in the mountains are red deer, roe deer, wild boar, rabbit and hare. The landscape is hilly and is characterized by a mosaic of vegetation types variously affected by pastoral activities. The silicate bedrock, acidic soils and land-use practices induce specific vegetation composition and patchiness. On sloping ground, the vegetation is dominated by heather moorland of Calluna vulgaris, Erica sp., Molinia caerulea and patches of Ulex europaeus and Pteridium aquilinum. Some slopes, especially the steepest ones, are dominated by deciduous forest patches of beech (Fagus sylvatica) and oak (Quercus robur). Intensively-grazed pastures are prevalent on the smooth mountain crests.

A preferential design was applied to select 35 sites based on the degree of landscape openness and current land-use across the Sourzay basin and centred on the fossil pollen record site (Fig. 1). Thus, the major relevant vegetation types and gradients of grazing pressure, from open to forested areas, were covered. Vegetation communities and their species composition are summarized in Table 1 . The most open and intensively grazed ones are sheep enclosure edges, and three types of grassland (overgrazed, poached and 'grazed wet vegetation'). More details on the vegetation survey and the classification of vegetation communities are described in Mazier et al. (2006).

At each site, up to ten moss polsters were randomly collected (in September of 2002) and mixed together into one sample per site. Whenever possible, moss species with dense, compact life forms were chosen (Boyd 1986), except for wet sites where Sphagnum sp. were collected. The amount of dung and degree of browsing and trampling were visually estimated as a proportion of the surveyed 


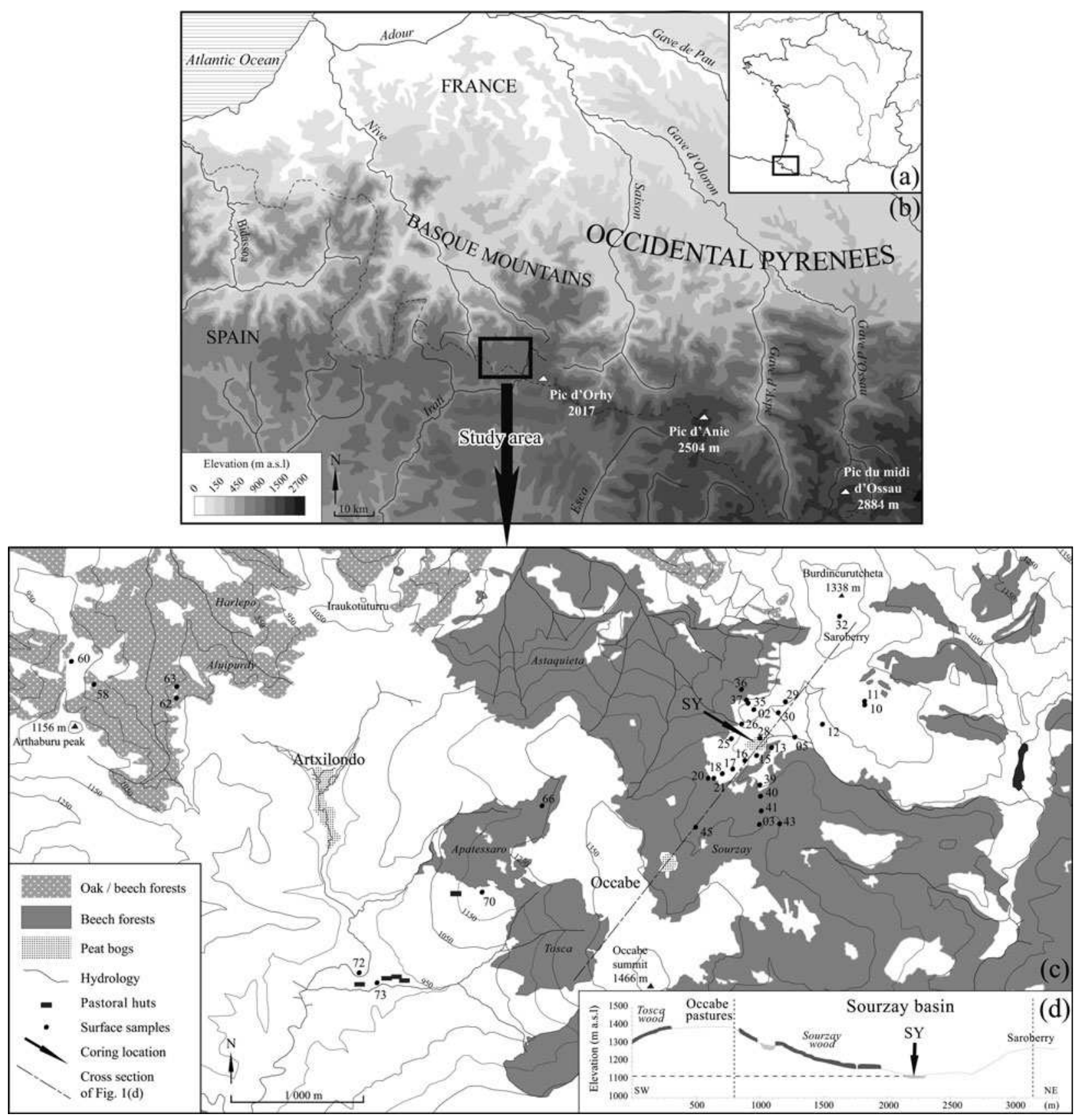

Fig. 1 a, b Study area in the Iraty Massif, Western Pyrenees, France; c location of the 35 surface samples (moss pollsters) selected for the study of modern NPPs and coring location on Sourzay peat bog (SY); d cross section showing the location of SY peat bog in the small Sourzay basin

surface showing recent signs of cattle activity (Mazier et al. 2006) and then compiled to Total Grazing Pressure (TGP) (semi-quantitative variable ranging from 0 to 9).

Modern moss samples were treated according to standard pollen preparation procedures (Faegri and Iversen 1989), being boiled in $10 \% \mathrm{NaOH}$, sieved at $250 \mu \mathrm{m}$, treated with cold $10 \% \mathrm{HF}(24 \mathrm{~h})$ and acetolysis (7 min). NPP identification followed van Geel's terminology (e.g. van Geel 1978) for known types; these types are indicated in the text as 'HdV-xxx' (e.g. HdV-733 or Sporormiella
(HdV-113); HdV = Hugo-de-Vries Laboratory, University of Amsterdam, The Netherlands). New microremains found in this study are coded as "TM-xxx" (TM = University of Toulouse-le Mirail, Toulouse, France). Some finds are illustrated in Fig. 2. As modern NPPs were counted independently from pollen grains it was not possible to express their values as percentages of the total pollen sum, as is usually done. NPPs are expressed as percentages of the total sum of NPPs (TNPP) that excludes type TM-B due to its overrepresentation in some samples. 
Table 1 Description of the 35 sampling sites used for the study of modern NPPs

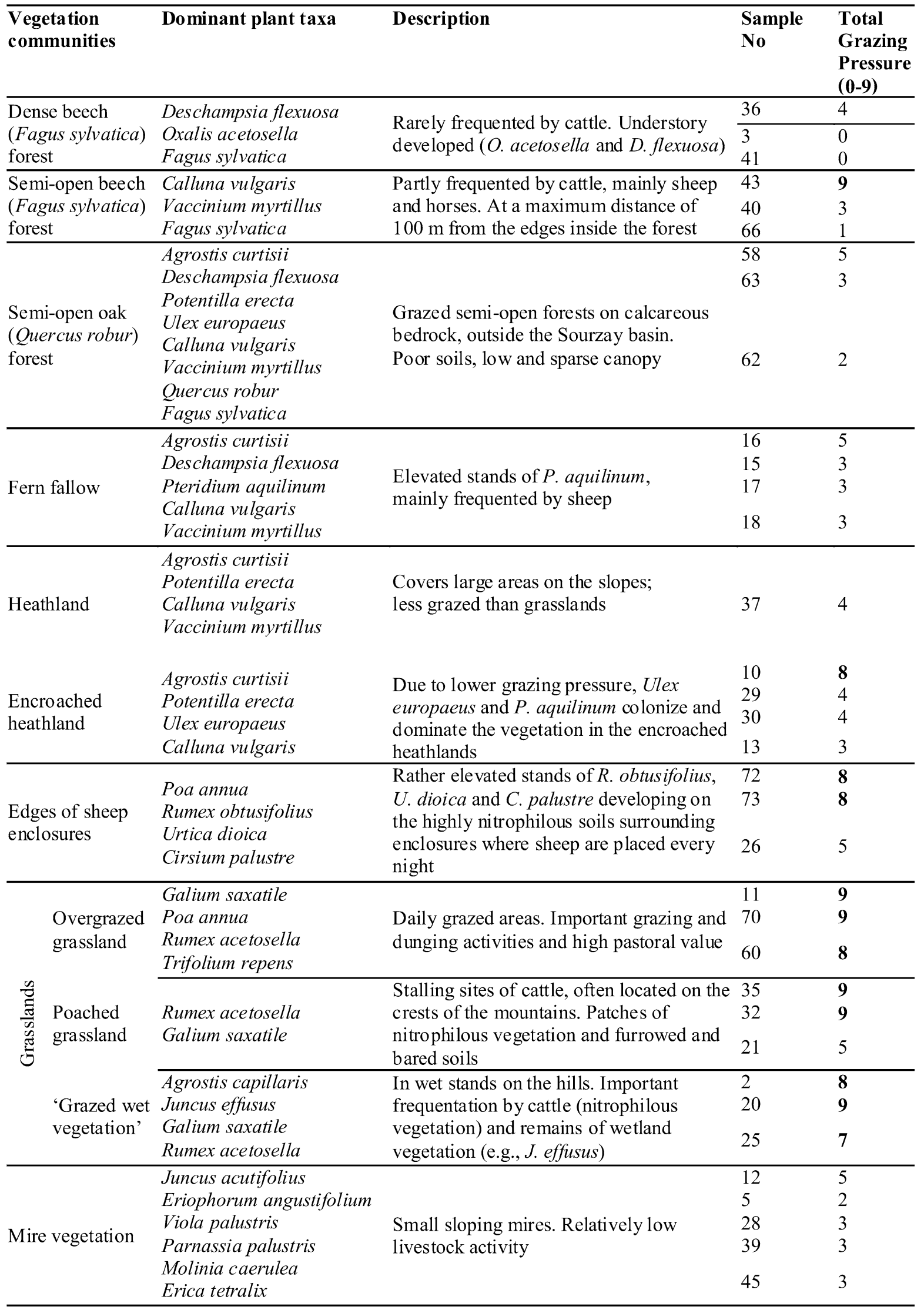


Fossil dataset—pollen and non-pollen palynomorphs

The Sourzay peat bog (SY) $\left(43^{\circ} 02^{\prime} 54^{\prime \prime} \mathrm{N}, 1^{\circ} 05^{\prime} 50^{\prime \prime} \mathrm{E}\right.$, $1,130 \mathrm{~m}$ a.s.l.) is located at the bottom of the small Sourzay basin which is currently used as a summer pasture and is partly surrounded by beech forests (nearest edges are at 150-200 m away from the bog, Fig 1). Local vegetation on the peat bog is dominated by Eriophorum angustifolium, Juncus acutiflorus, Molinia caerulea ssp. caerulea, Erica tetralix and Calluna vulgaris.

A sediment core of $57 \mathrm{~cm}$ length (peaty silt from a depth of $57-53 \mathrm{~cm}$ and peat from $53 \mathrm{~cm}$ to the top) was retrieved using a Russian peat sampler. 27 peat samples were taken at $2 \mathrm{~cm}$ intervals, except for the top of the core $(1$ and $3 \mathrm{~cm}$ intervals), prepared using the same treatments as for the modern samples (see above) and analysed for pollen and NPPs. The spectra $57 \mathrm{~cm}$ was sterile of NPPs. The level of NPP identification was harmonized as far as possible with that used in the modern dataset. Fossil NPPs are expressed as percentages of the sum of total pollen plus NPPs (TLP + TNPP). The pollen analysis method is described in detail in Mazier et al. (2009). Pollen grains were identified to the most precise taxonomic level possible, using pollen keys (Faegri and Iversen 1989; Moore et al. 1991; Reille 1992-98). Aquatics, fern spores and hygrophilous plants (including Cyperaceae) were excluded from TLP.

The chronology of the Sourzay fossil record is based on 6 AMS radiocarbon dates performed on bulk sediment (Table 2). The ${ }^{14} \mathrm{C}$ dates were calibrated at two sigma cal age yr B.P. intervals using CALIB 5.1 software (Stuiver and Reimer 1993) based on the INTCAL04 curve (Reimer et al. 2004). Ages were estimated along the profile using linear interpolation between median probabilities (Mazier et al. 2009). The Sourzay fossil record documents the last ca. 2,000 years.

\section{Numerical analysis}

In order to describe the major gradients in the modern non-pollen palynomorph assemblages and to relate them to the vegetation types, Correspondence Analysis (CA) was performed on non-transformed data. Single types were omitted. Types present in a few samples $(<3)$ with low counts $(\leq 3)$ were considered as passive descriptors. Ordination analyses were implemented by the software SPAD 5.5 (Decisia 2002).

The relation between coprophilous fungi and the degree of grazing pressure was also evaluated. Thirteen modern sporetypes of dung-related Ascomycetes found in sufficient values were selected. Eight known types (Davis 1987; van Geel et al. 2003; Davis and Shafer 2006; van Geel and Aptroot 2006, references therein) were encountered: Sporormiella (HdV-113), HdV-55 (Sordaria (HdV-55A) and HdV-55B), Podospora (HdV-368), Apiosordaria verruculosa (HdV-
169), Cercophora (HdV-112), Chaetomium (HdV-7A), Coniochaeta cf. ligniaria (HdV-172) and Gelasinospora (HdV-1). Five spore-types were added according to Bell (2005), Ellis and Ellis (1998), Lundqvist (1972) and Richardson and Walting (1982): Trichodelitschia (HdV-546), Delitschia (TM-023A-B, TM-006), Coniochaeta A (TM016), Coniochaeta B (TM-211) and a group of Sordariaceous ascospores undifferentiated (undiff.). Frequencies (\% TNPP) of the thirteen selected spore-types were compared between two categories of sites corresponding to two grazing pressure regimes: category A (23 samples) corresponds to non- to moderately-grazed sites (TGP from 0 to 5 ) and category B (12 samples) corresponds to intensively-grazed sites (TGP from 7 to 9). Differences were tested by means of a median test that compares frequencies of the type/group of types in each category to the general median of the type/group of types in the whole dataset (contingency table, $2 \times 2$ ). Chisquare statistics give significance of the differences to $95 \%$ confidence level (CL), $\mathrm{fd}=1$.

\section{Results}

Modern dataset of non-pollen-palynomorphs

NPP results of surface samples are presented as a percentage diagram (Fig. 3). Several fungal spores are dominant in the beech forests, particularly conidia of Mitosporic fungi (Hyphomycetes and Coelomycetes). These are Asterosporium sp./Triposporium elegans (TMM2-1, with dominance of Asterosporium sp.), Brachysporium cf. obovatum (TM-014), Endophragmiella A, B and C (TM-009, TM-224, TM-227) and Trichocladium opacum (TM-011). Xylariaceous ascospores undiff. and Ustulina deusta (HdV-44) are also characteristic of beech forests, $U$. deusta being to a great extent less common than the Xylariaceous ascospores undiff. Other spores, less abundant, are Splanchnonema foedans (TM-019), cf. Brachysporium sp. (cf. HdV-494), TM-015 and Pteridosperma sp. (TM-021).

Spectra from semi-open oak forests are characterized by fungi also associated with other vegetation communities, notably fern fallows and heathland: TM-O, TM-N, HdV495 and HdV-733. Except for TM-B and some dung-related Ascomycetes, few types appear specifically associated to the grasslands. TM-B shows clear preferences for grassland and heathland (with or without Ulex sp.).

Dominant fungal types in spectra from mire vegetation are Tilletia sphagni (HdV-27), Teliospores undiff., Entophlyctis lobata (HdV-13) and Appresorium 1. HdV-10, 16 and 18 are rare but almost restricted to mires. Thecamoeba (except Assulina muscorum (HdV-32A)), and to lesser extent zoological remains of Copepoda ( $\mathrm{HdV}-28)$, 

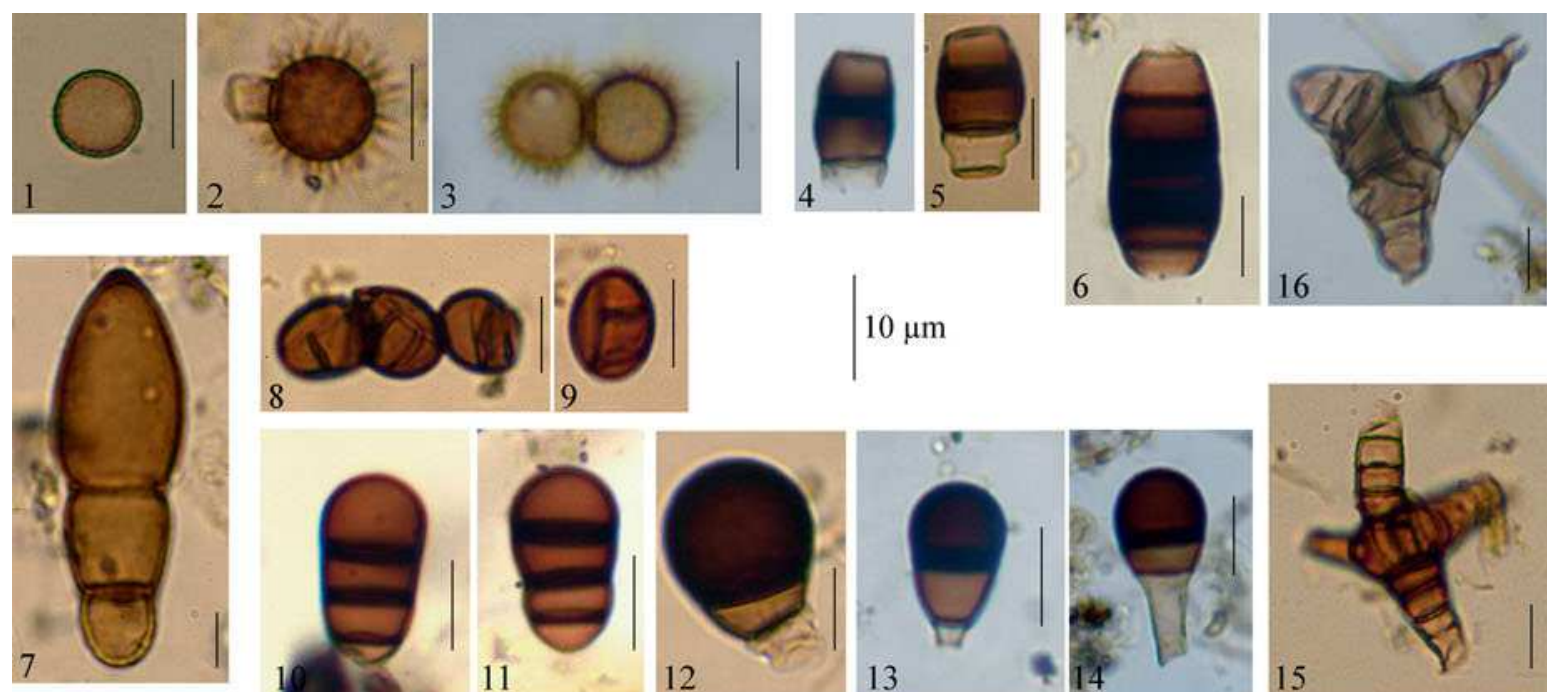

$10 \mu \mathrm{m}$
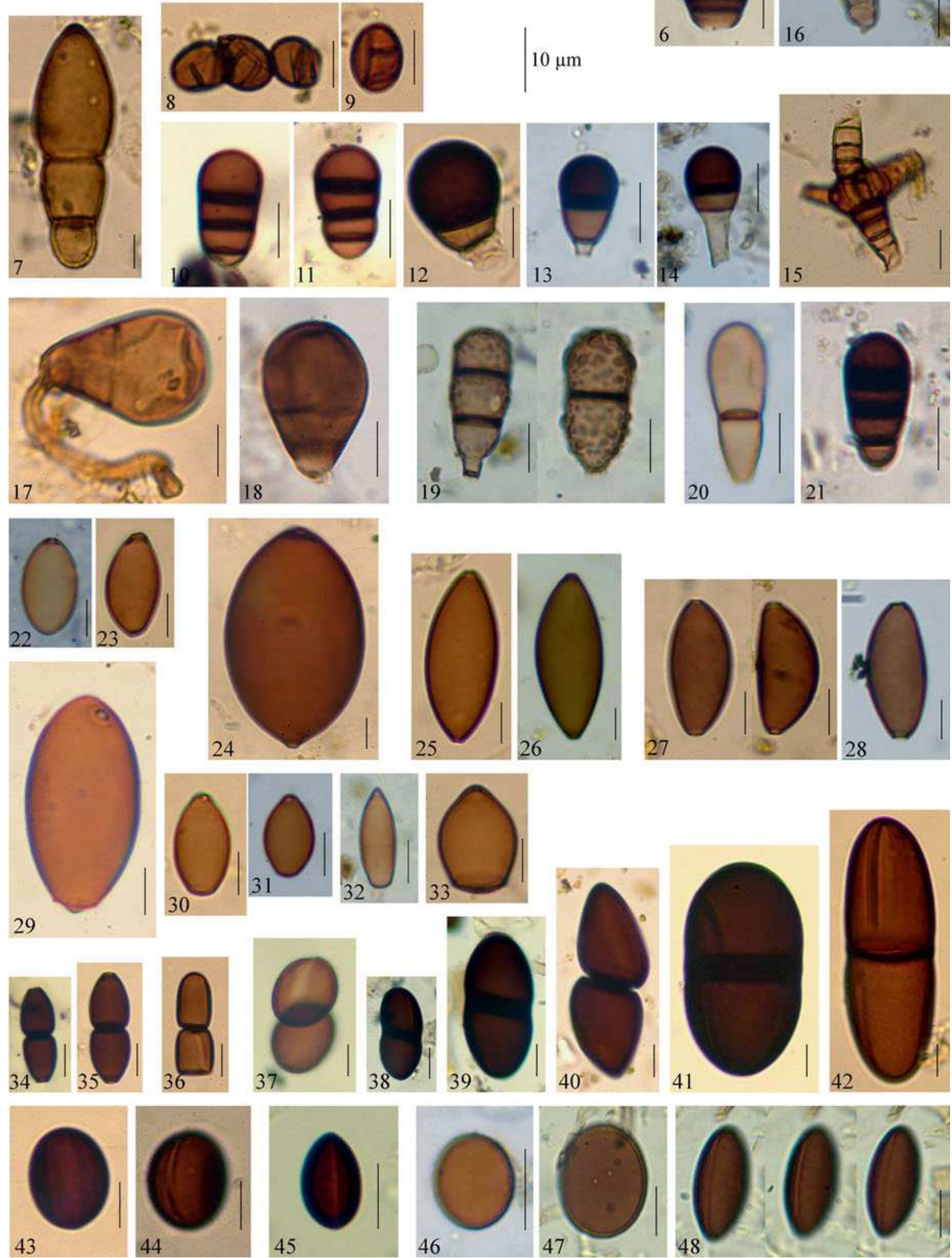
4 Fig. 2 Fossil (numbers in italics) and extant fungal spores from the Iraty Massif, Western Pyrenees, France; bar is $10 \mu \mathrm{m}$. 1, TM-B (basidiospore of Gasteromycete?); 2-3, HdV-495; 4-5, TM-O (parts of conidia?); 6, TM-036 (conidium); 7, cf. Splanchnonema foedans (TM-019, ascospore); 8-9, TM-015; 10-11, cf. Endophragmiella C (TM-227, conidium); 12, cf. Endophragmiella A (TM-009, conidium); 13-14, cf. Endophragmiella B (TM-224, conidia); 15, Triposporium elegans (TM-M1, conidium); 16, Asterosporium sp. (TM-M2, conidium); 17-18, Brachysporium obovatum (TM-014, conidia); 19, Trichocladium asperum (TM-F, conidium); 20, cf. Trichocladium sp. (HdV-572, conidium); 21, cf. Trichocladium opacum (TM-011, cf. HdV-569?, conidium); 22-23, Sordaria (HdV-55A); 24, cf. Sordaria (included in HdV-55B); 25-26, Sordariaceous ascospores (included in HdV-55B); 27-28, TM-H; 29, Podospora (HdV-368); 30-31, cf. Podospora polysporus (TM-110); 32, Cercophora (HdV-112); 33, Apiosordaria verruculosa (HdV-169); 34-35, Trichodelitschia (HdV546); 36, Sporormiella (HdV-113, two part-spores still attached); 3742, Delitschia spp.; 43-44, Coniochaeta cf. ligniaria (HdV-172); 45, Coniochaeta A (TM-016); 46-48, Coniochaeta B (TM-211)

Rhabdocoela (HdV-353B) and Callidina angusticollis (HdV-37), occur regularly in spectra from mire vegetation.

The dung-related Ascomycetes show different patterns. Sporormiella, HdV-55, Podospora and Trichodelitschia present similar trends and have higher values in sites with high TGP, especially the grasslands. Sporormiella is highly abundant in comparison to the other types. Delitschia, Apiosordaria and Chaetomium are less frequent and less abundant, but predominantly recorded in the grasslands. Coniochaeta A, Cercophora and Gelasinospora, always present in low values, are more frequent in forested sites than other sites. Coniochaeta B is very common and abundant, with higher values in fern fallows and heathland.

\section{Correspondence analyses}

In a first CA (61 types and 35 sites), NPP assemblages from wetland communities ( 3 sites) and an oak forest (1 site) were clearly separated from the remaining sites (Cugny unpublished). These sites contained taxa characteristic of mire vegetation (Amphitrema flavum (HdV-31), Assulina seminulum (HdV-32B), Tilletia sphagnii and Teliospores undiff.) and of one oak forest (Trichocladium asperum (TM-F)). This caused a long gradient in the ordinations, which resulted in a poor separation of the other samples.
Therefore, a CA on 31 samples and 56 NPP types was performed to illustrate the relationship between fungal spores and terrestrial vegetation communities (Fig. 4).

The two-first axes explain $33.2 \%$ of the total variance and depict the most important direction of variation in the dataset. Axis $1(19.93 \%)$ reflects the degree of openness as it separates beech forests (sites 66, 41, 40, 3, 43 and 36: $45 \%$ of the variance of axis 1) from grassland and heathland (sites 13, 37, 70, 21 and 32: 44.6\%). Axis 2 (13.27\%) is more difficult to explain as it discriminates beech forests and open sites from various vegetation communities (heathland, fern fallows and open oak forest).

Cercophora, Coniochaeta A, Gelasinospora, and to a lesser extent Coniochaeta cf. ligniaria, are related to the beech forests. HdV-55 is plotted between beech forests and the other sites due to important records of the type in the ungrazed beech forest 3 (Fig. 3). Chaetomium is related to TM-B spores in the grasslands and heathlands, owing to important records in sample 70 .

Testing modern coprophilous Ascomycetes and grazing pressure relationships

Figure 5 shows the distributions in percentages of dungrelated Ascomycetes spore-types (Fig. 5a, b) and sporetype assemblages (Fig. 5c) for two categories of sites A and B defined as sites with low (0-5) and high (7-9) TGP, respectively. Spore-types are grouped according to their patterns between the two grazing pressure categories into Group 1 (Fig. 5a) and Group 2 (Fig. 5b).

Within Group 1 (Fig. 5a), Sporormiella, HdV-55 and Podospora show significantly higher percentages in category B; Sporormiella shows the highest correlation with grazing pressure. Although Trichodelitschia presents higher percentages in category B, there is no significant difference to 95\% CL. Apiosordaria, Delitschia and Chaetomium, present with low values in few samples, are more frequent in category B and so are therefore positively linked with TGP.

In Group 2 (Fig. 5b) the relationship between Coniochaeta $\mathrm{B}$ and TGP is unclear. It presents its maximum value in category A, its best median value in category B, and no significant relation to grazing pressure. Cercophora,

Table 2 Radiocarbon dates (AMS ${ }^{14} \mathrm{C}$ dating) performed on the peat record from Sourzay, Iraty Massif, Western Pyrenees, France

\begin{tabular}{llclll}
\hline Lab. code & Sample & Depth $(\mathrm{cm})$ & ${ }^{14} \mathrm{C}$ age $(\mathrm{yr}$ в.P. $)$ & cal yr B.P. $2 \sigma$ range & Median $(\mathrm{Cal}$ yr B.P.) \\
\hline Vera-2552 & Peat & $11-13$ & Modern & - & - \\
Poz-13477 & Peat & $18.5-19.5$ & $180 \pm 30$ & $0-300$ & 180 \\
Poz-6340 & Peat & $26.5-27.5$ & $300 \pm 30$ & $295-460$ & 387 \\
Vera-2553 & Peat & $31-32$ & $400 \pm 35$ & $320-515$ & 467 \\
Poz-13478 & Peat & $38.5-39.5$ & $755 \pm 30$ & $665-730$ & 689 \\
Beta-167161 & Peaty silt & $54-56$ & $1980 \pm 40$ & $1825-2035$ & 1931 \\
\hline
\end{tabular}


Gelasinospora, Coniochaeta A and C. cf. ligniaria, are not positively linked with TGP.

Cumulative percentages of spore-types of Group 1 are clearly and significantly higher in category B while those of Group 2 reveal no significant relation to TGP (Fig. 5c). The cumulative percentages of the complete coprophilous spectrum (all of the 13 spore-types) remain significantly higher in category $\mathrm{B}$.

Fossil record from Sourzay (SY)

The NPPs and pollen records are presented in Fig. 6. Main changes in pollen and non-pollen palynomorph assemblages are described for each NPP Assemblage Zone (NPPAZ) in Table 3. Fourteen spore-types of dungrelated Ascomycetes were found in the fossil samples. They are grouped into two coprophilous assemblages (Groups 1 and 2) according to their relation to grazing pressure in the modern dataset (Fig. 5); the establishment of two coprophilous assemblages is discussed in the "Discussion" section. The new type cf. Podospora polysporus (TM-110) is included in the coprophilous Group 1 according to the ecology of Podospora (genus mainly composed of coprophilous species according to Krug et al. 2004) and to its trend relative to the other types included in Group 1 (Fig. 6). HdV-55 was differentiated in Sordaria (HdV-55A) and HdV-55B. Note that NPP frequencies are expressed as percentages of the sum of total pollen plus NPPs (\% TLP + TNPP).

\section{Discussion}

Association of modern fungal microremain assemblages with different vegetation communities

Pools of modern NPPs, dominated by airborne fungal spores, are associated with specific vegetation communities related to degree of openness (beech forests/heathland and

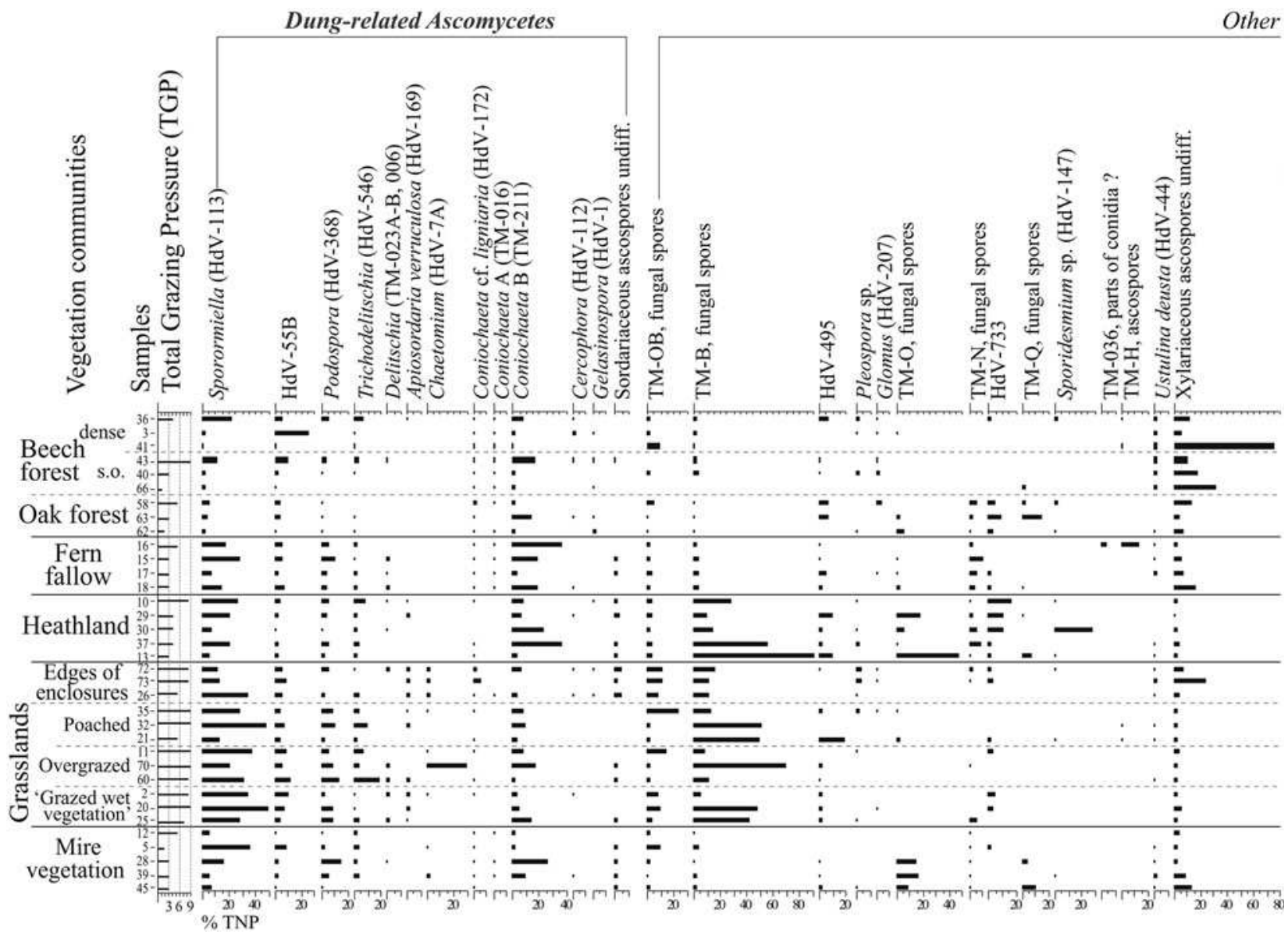

Fig. 3 Diagram of modern NPP assemblages from the Iraty Massif, Western Pyrenees, France, ordered according to vegetation types. NPPs are expressed as percentages of Total Non-Pollen
Palynomorphs (\% TNPP), excluding spore-type TM-B. Total NPP counts $(\mathrm{N})$ showed on the right-hand margin 
grassland, Figs. 3, 4). Mulder and Janssen (1999) also showed that fungal spores discriminated vegetation types along a transect across oak forest and heathland.

Beech forests are characterized by an ecologically consistent assemblage of saprobe or parasitic fungi on woody substrates. Conidia of mitosporic fungi (Brachysporium obovatum, Triposporium elegans, Asterosporium sp., Endophragmiella spore-types, Trichocladium opacum) mostly belong to saprobe or parasitic taxa commonly associated with woody substrates (living, dead or decaying wood, bark, twigs, leaves or litter; cf. Ellis (1971), Ellis and Ellis (1985), and Kiffer and Morelet (1997)). Xylariaceae comprise species of different trophic affinities (e.g. coprophilous, lignicolous, parasitic). In this present case, the Xylariaceous ascospores undiff. are particularly well associated with forested environments which suggests that the spore-type predominantly encompasses saprobe (or parasitic) species on woody substrates. However, some types (e.g. Ustulina deusta, Xylariaceous ascospores undiff., B. obovatum, Endophragmiella B) can occur in other sites located at a distance from forests (>100 m; e.g. samples $72,73,32,29$, 12, 11 or 10, Figs. 1, 3).

Despite the lack of information on their ecology, some fungal types seem indicative of semi-open and open landscapes. Oak forests present similar herb and shrub species composition to heathland and fern fallows (Table 1). These vegetation communities may provide similar habitats (e.g. comparable host plants, light or moisture conditions) for fungi producing TM-N, TM-O, HdV-495 and HdV-733 spore-types (Fig. 3). The unknown TM-B spore-type, mostly found in heathland and grassland (Figs. 3,4), seems to be indicative of open environments. TM-B spores (Fig. 2) may be related to above ground Gasteromycetes (puff balls) and the high proportion of records concurs with this taxonomic affiliation. Aptroot (2006) stressed the importance of Gasteromycetes spores in palaeoecological studies as they may vary between open and forested environments. Even if the taxonomic affinity of TM-B spores is still to be confirmed, there is evidence for specific ecological preferences of this type. More precise investigations of an extended modern dataset with

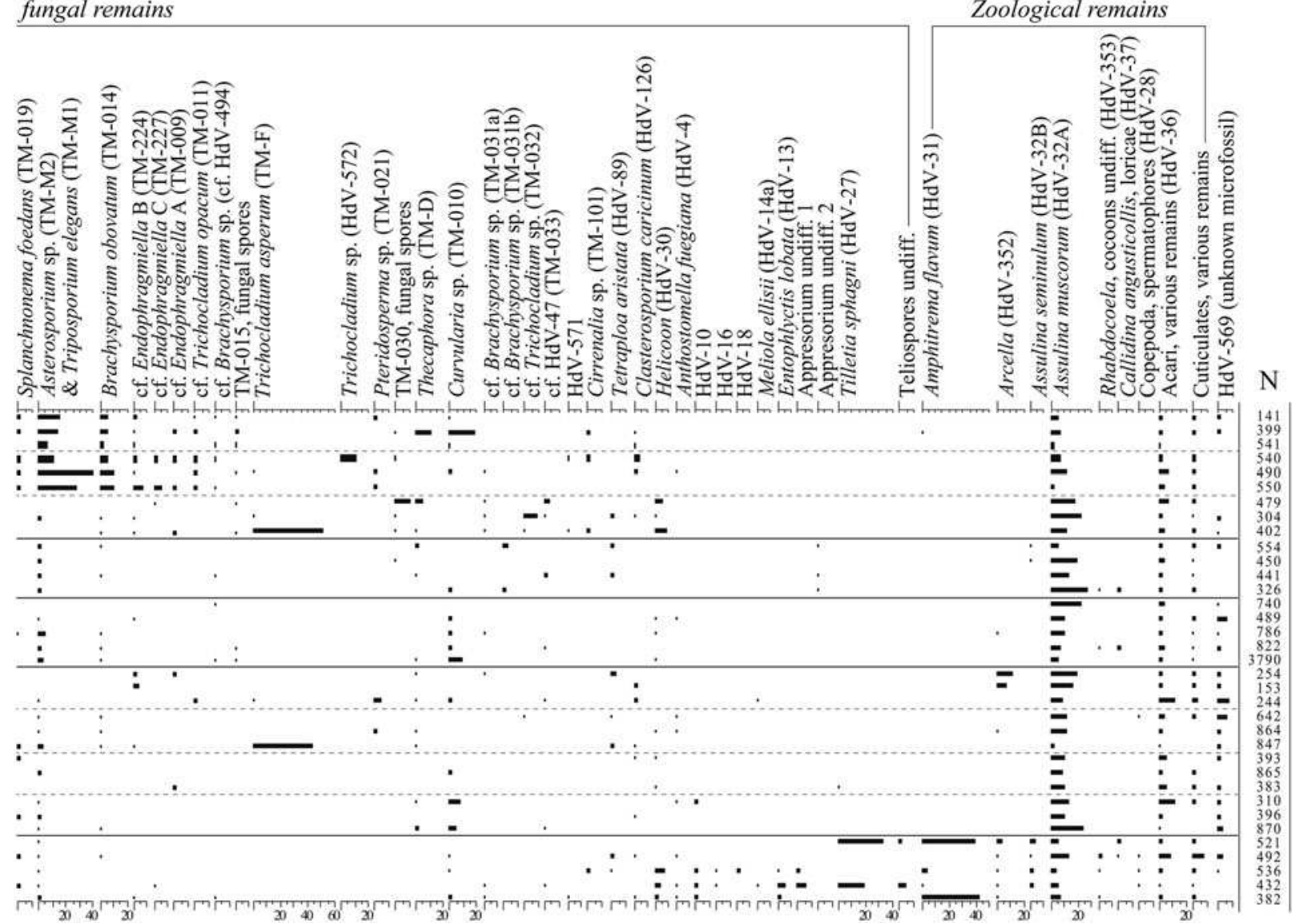

Fig. 3 continued 


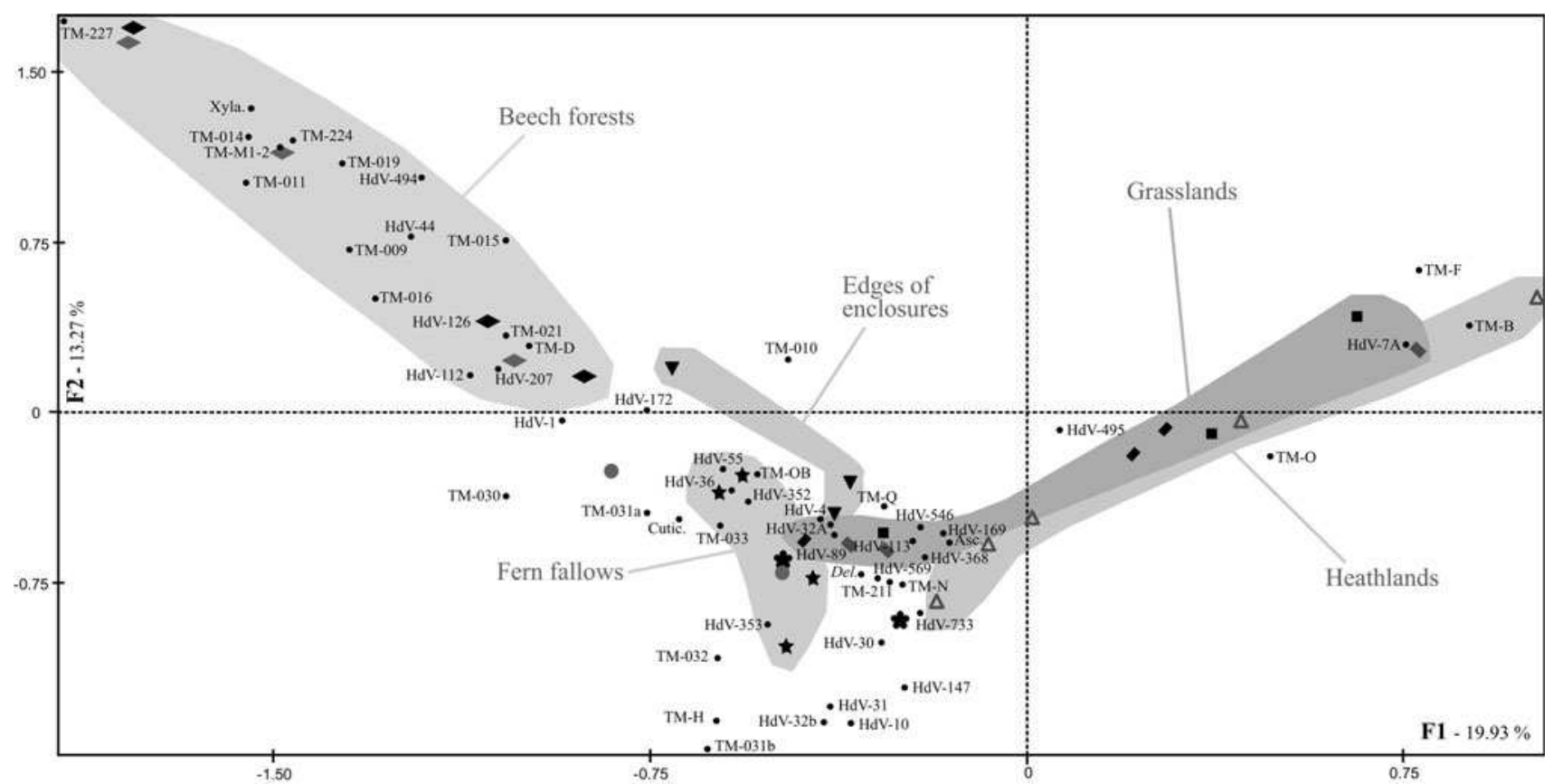

Fig. 4 Correspondence analysis of modern NPPs performed on 56 types (small black circles) and 31 sites (geometric symbols). Sites differentiated according to vegetation types: black and grey diamonds, dense and semi-open beech forests; grey circles, open oak forests; black stars, fern fallows; open triangles, heathlands and encroached heathlands; inverted black triangles, edges of sheep enclosures; black squares, poached grassland; inverted grey rectangles, overgrazed grassland; inverted black rectangles, 'grazed wet

information on environmental conditions (e.g. soil reaction, soil moisture, $\mathrm{N}$ availability, substrates for fungi) might help in the understanding of these unknown fungal types.

Degrees of coprophily of modern dung-related Ascomycetes spore-types

The cumulative percentages of 13 selected types were significantly higher in intensively-grazed sites (Fig. 5c). This confirms that the complete spectrum of dung-related Ascomycetes spore-types is relevant to the reconstruction of herbivore population densities (van Geel et al. 2007) and may prevent erroneous interpretation of an extreme value originating from one single spore-type (e.g. high records of HdV-55 and Chaetomium in samples 3 and 70, respectively; Fig. 3). Nevertheless, spore-types individually showed different responses to grazing pressure (Figs. 3, 5) and patterns between sites (Figs. 3, 4). An assessment has been attempted to see whether they were of different dung indicative values.

Saprophytic fungal species occurring on dung possess different degrees of coprophily (i.e. species specific to dung habitat; more generalist coprophilous species able to grow on other kinds of decaying substrates; species on other substrates which can occasionally colonize dung; Cooke and vegetation'; black asterisks, mire vegetation. Vegetation types are manually grouped (grey areas). Numbers refer to HdV-types or TM-types as shown on Fig. 3 and mentioned in the text. Additional abbreviations: Asc.-Sordariaceous ascospores undiff.; Apr1-Appresorium 1; Cutic-Cuticulates, various remains; Del-Delitschia (TM-006, TM-023A-B); Telio-Teliospores undiff.; Xyla-Xylariaceous ascospores undiff

Fig. 5 Boxplots of percentages (showing median, first and third quartiles, minimum and maximum percentages) of dung-related Ascomycetes spore-types and assemblages for two categories of Total Grazing Pressure (TGP). Category A: $n=23$ sites under low to moderate grazing pressure (TGP: $0-5$ ). Category B: $n=12$ sites under high grazing pressure (TGP: 7-9). Differences assessed by comparing values of the type/types assemblage in each category to the general median of the type/types assemblage in the dataset $(2 \times 2$ contingency table). Liaison with TGP indicated as \pm (positive/negative) for significant differences assed by $\chi^{2}$ statistics to $95 \% \mathrm{CL}$ (significant if $p<0.05$ ), $\mathrm{fd}=1$. a GROUP 1: dung-related Ascomycetes positively linked with the grazing pressure (explanations on the inclusion of Trichodelitschia given in the text). b GROUP 2: dung-related Ascomycetes not positively linked with the grazing pressure. c Summary, showing cumulative values of spore-types of GROUP 1 and GROUP 2 and of the complete dung-related types spectrum (GLOBAL)

Rayner 1984). Ascomycetes contain numerous coprophilous species, and the dung-related Ascomycetes genera encompass a differing number of coprophilous species, themselves more or less specific to dung habitat (Krug et al. 2004). According to this, Krug et al. (2004) propose an estimation of the degree of coprophily for Ascomycetes genera (i.e. genera predominantly composed of coprophilous species; genera composed of species primarily on other substrates; mixed genera comprising many coprophilous and non- 
(a) Dung-related Ascomycetes - GROUP 1
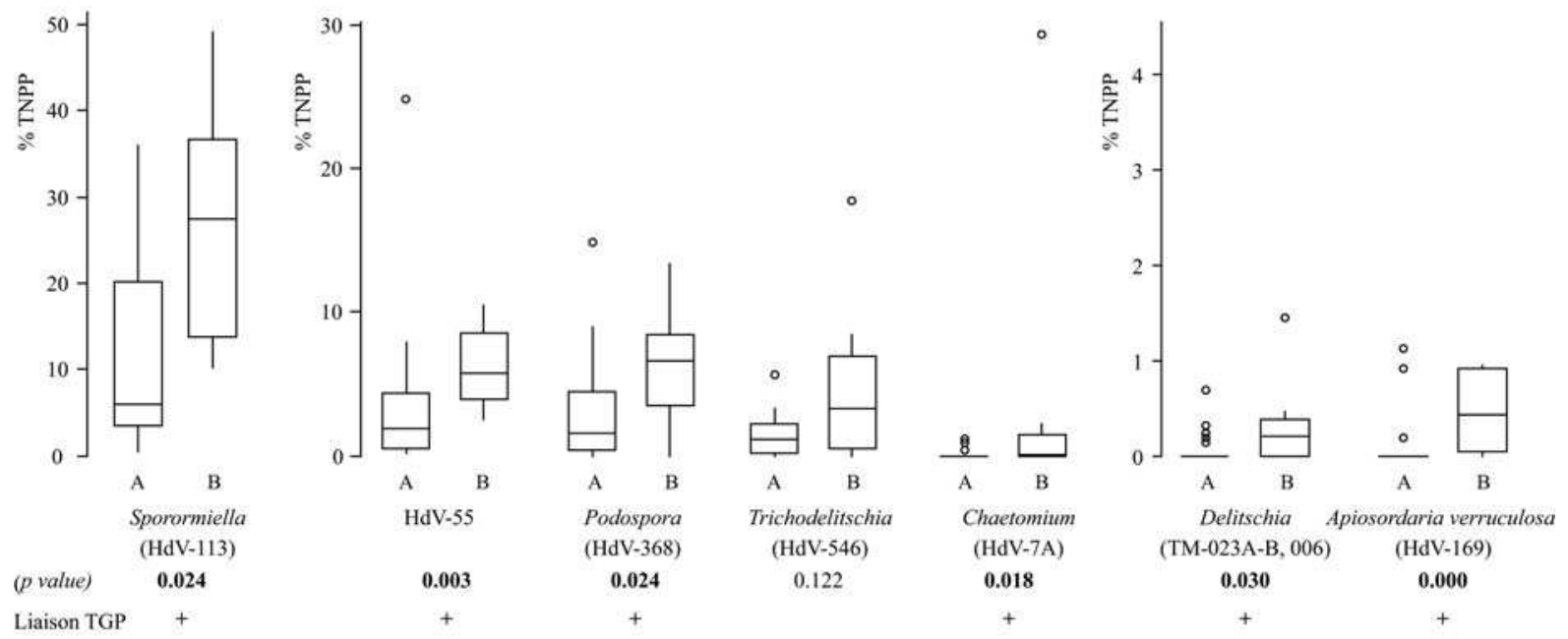

(b) Dung-related Ascomycetes - GROUP 2
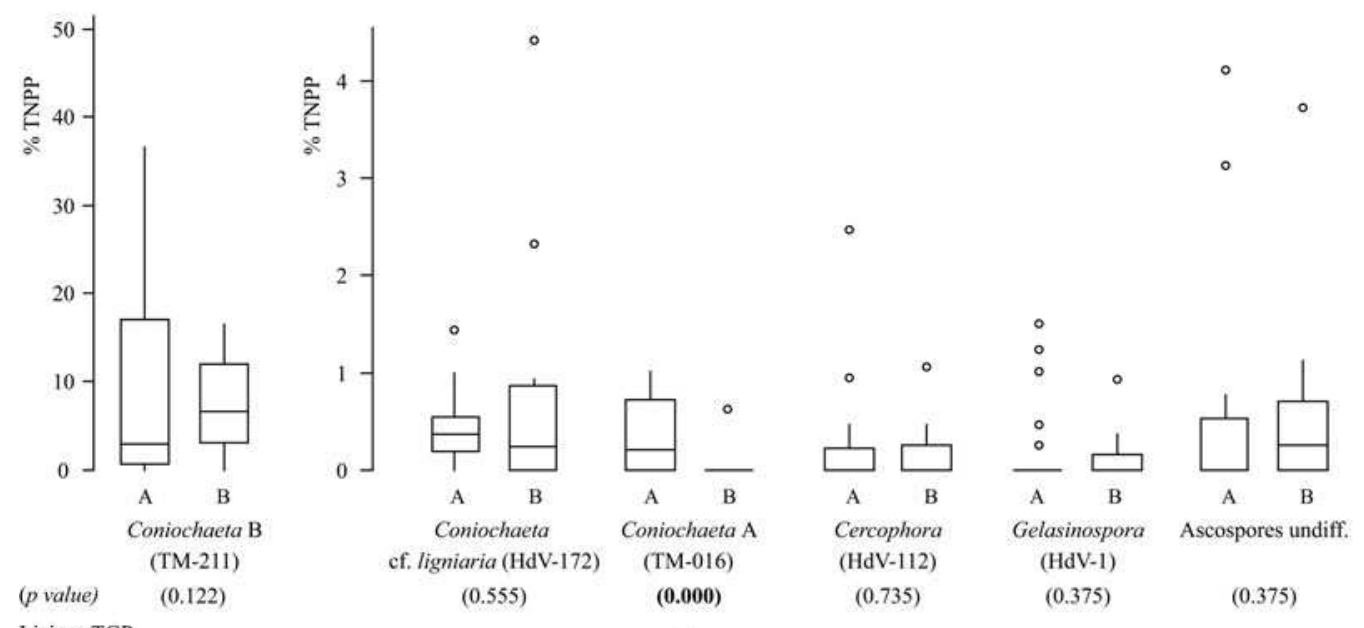

Liaison TGP (0.122)

\section{(c) ASSEMBLAGES}

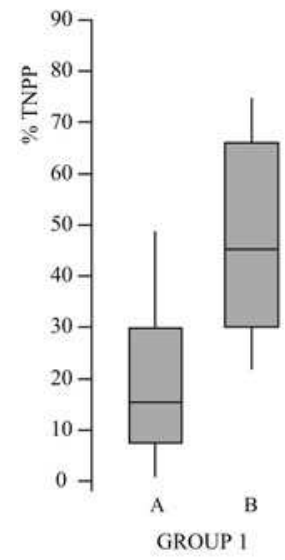

(p value) (0.024)

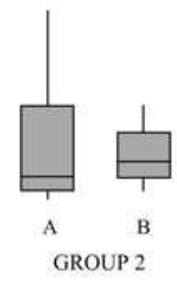

(0.903)

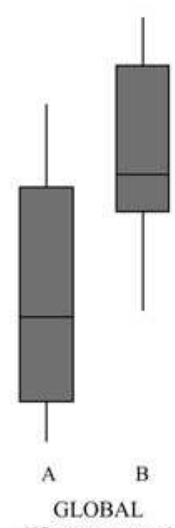

(13 spores-types) (0.012)

\footnotetext{
Liaison TGP +
} 


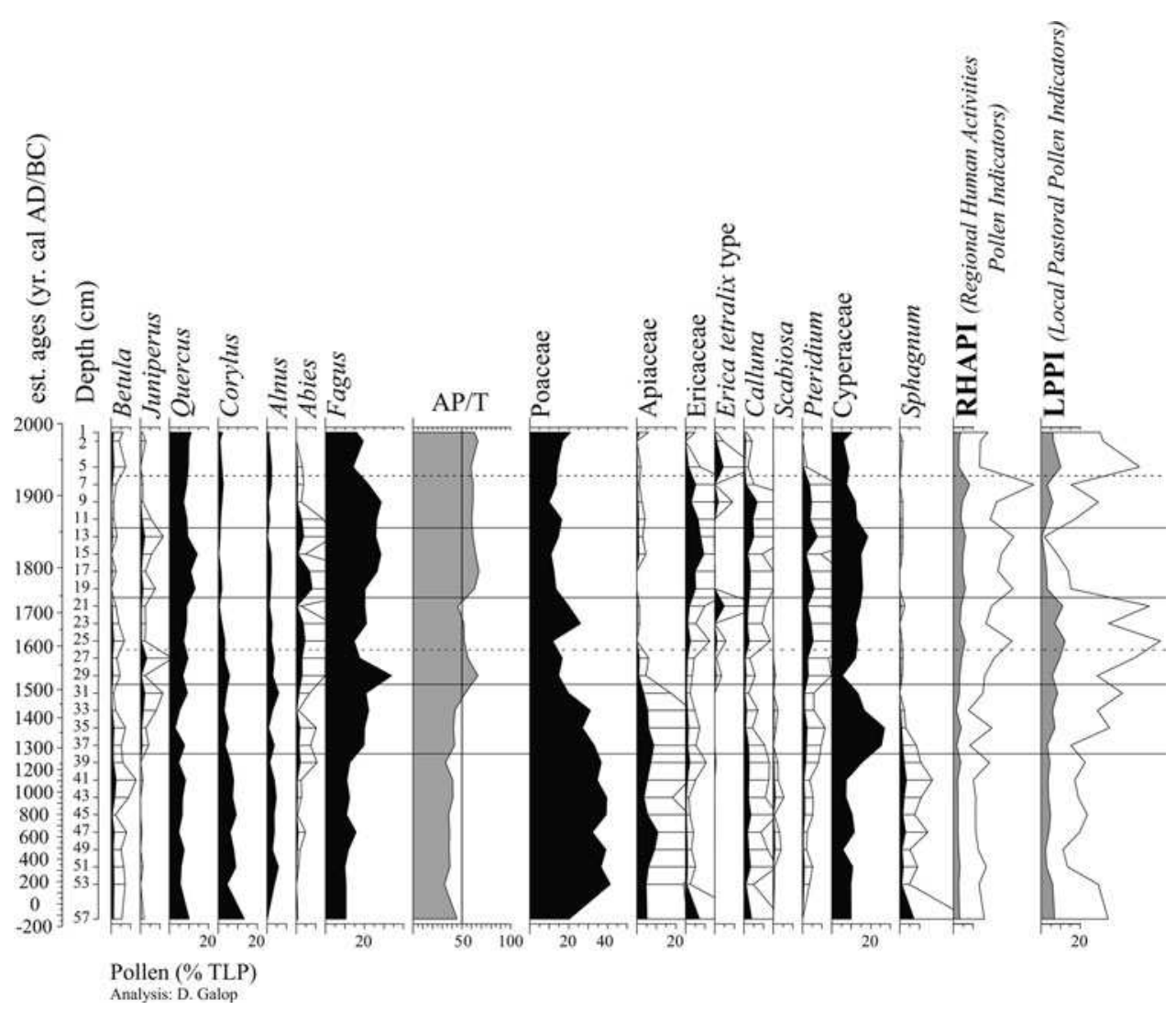

Fig. 6 Diagram of selected pollen and NPPs from the peat record from Sourzay, Iraty Massif, Western Pyrenees, France. NPPs expressed as percentages of sum of Total Pollen and NPPs $(\%$ TLP + TNPP). Exaggerated curves are $\times 5$. Coprophilous fungi grouped according to their relation with grazing pressure in the modern dataset (Groups 1 and 2, Fig. 5). LPPI: Asteroideae,

coprophilous species). Spore-types, mostly identified to genus-level, may then include species of different degrees of coprophily. Some spore-types, such as Coniochaeta cf. ligniaria or Apiosordaria verruculosa, refer to one or few species while others may involve a wide range of species, e.g. Cercophora, Sporormiella, Sordaria or HdV-55.

The genera Sporormiella, Podospora and Sordaria, predominantly composed of coprophilous species (Krug et al. 2004), are also among the most commonly encountered on dung (Lundqvist 1972; Ellis and Ellis 1998; Krug et al. 2004; Bell 2005). In the dataset, Sporormiella, Podospora and HdV-55 (i.e. Sordaria (HdV-55A) and HdV-55B, including probably Sordaria spp. as well) are common, abundant and significantly correlated with TGP. They are therefore the most robust indicators of grazing activities. These present results are also consistent with palaeoecological studies. In particular, Sporormiella (including also possibly Sporormia and Preussia part-spores, van Geel and Aptroot 2006) has
Cichorioideae, Cirsium-type, Galium-type, Ranunculaceae, Stellaria-type and Potentilla-type. RHAPI: Secale, Cerealia undiff., Chenopodiaceae, Artemisia, Urtica dioica, Plantago lanceolata, Plantago media/major, Rumex sp., Rumex obtusifolius-type and Rumex acetosal acetosella

been shown to be a valuable indicator of past grazers' presence and density (Davis 1987; Burney et al. 2003; van Geel et al. 2003; Davis and Shafer 2006). However, the higher proportions of Sporormiella spore-type observed in the dataset could be related to the division of each spore into a minimum of four part-spores.

Although the genus Trichodelitschia is composed of four coprophilous species (Ebersohn and Eicker 1992; Bell 2005), the spore-type Trichodelitschia has never been reported as a dung indicator. The results show no significant correlation between Trichodelitschia and TGP (Fig. 5a). However, we cannot exclude it as a possible dung indicator considering both its similar trends to Podospora, HdV-55 and Sporormiella (Fig. 3) and the coprophilous ecology of the genus.

The types Apiosordaria verruculosa (soilborne and coprophilous species, cf. Bell 2005) Chaetomium (sporetype probably corresponding to one or few species from a 


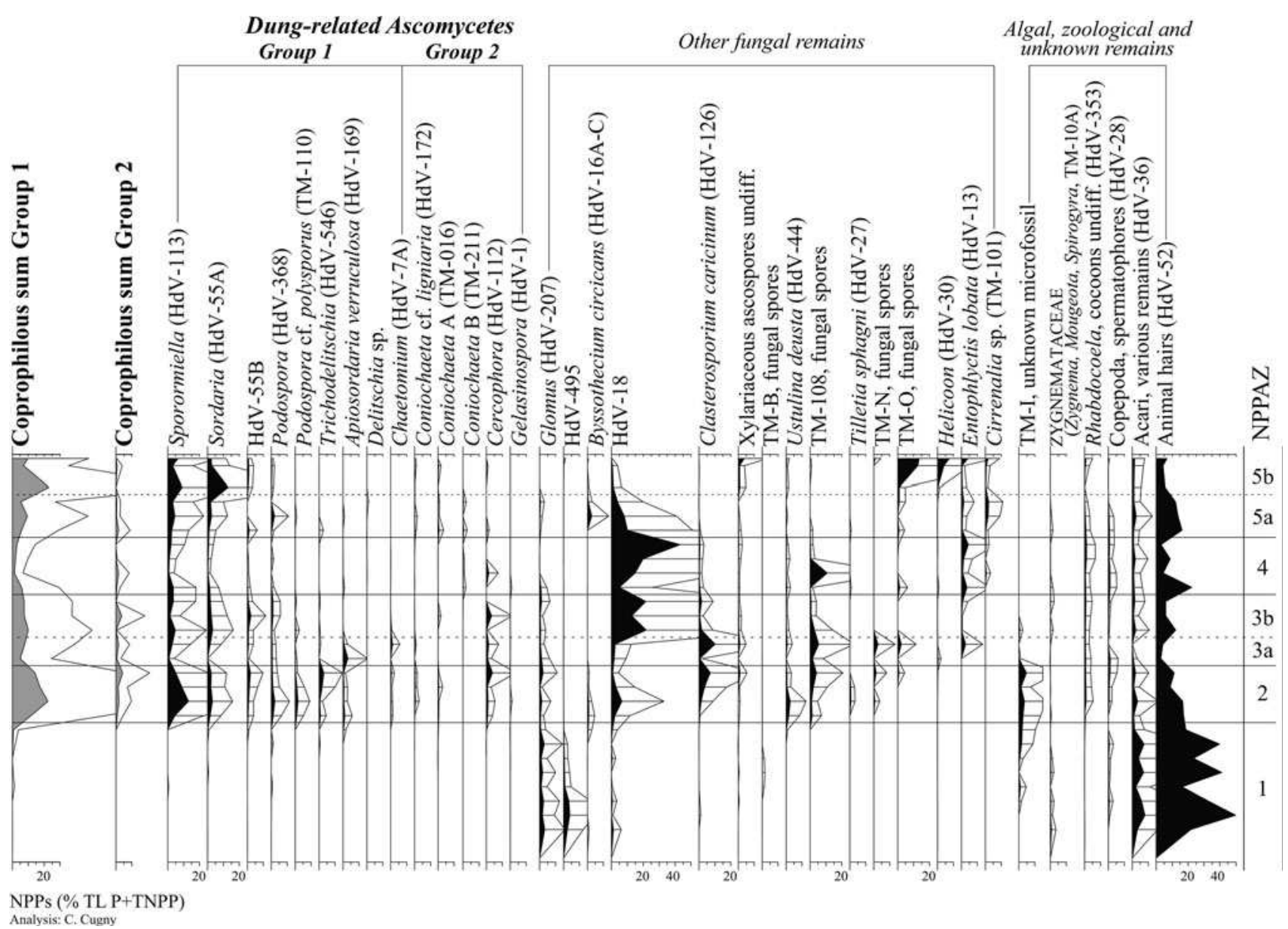

Fig. 6 continued

mixed genus, cf. Krug et al. 2004) and Delitschia (several spore-types from a mainly coprophilous genus, cf. Krug et al. 2004) are positively related to TGP (Fig. 5a), but are scarce compared to the previous types (Fig. 3). Their presence, rather than their abundance, provides additional information on intensively-grazed conditions.

Krug et al. (2004) assigned Coniochaeta, Cercophora and Gelasinospora to mixed genera comprising many coprophilous and non-coprophilous species. Here, Cercophora, Gelasinospora, Coniochaeta cf. ligniaria and Coniochaeta A show no positive relation with TGP (Fig. 5b) and appear to be more related to forested environments (especially Coniochaeta A, Figs. 3, 4). Although the potential dung indicative value of these spore-types cannot be completely rejected, they may reflect heterogeneous trophic affinities. More observations within grazed and ungrazed forests are needed in order to determine the extent of habitat preference and of substrate affinities in their ecology. Coniochaeta B (Fig. 2) is morphologically similar to spores of Coniochaeta sp. identified by Aptroot and van Geel (2006) in permafrost samples from underneath the Yukagir Mammoth. In the dataset, Coniochaeta
B, abundant on heathland and fern fallows (Fig. 3), presents no correlation with TGP (Fig. 5b). Whether the spore-type encompasses coprophilous species requires further observation as this may reveal habitat preferences.

The dung-related Ascomycetes can be divided into two groups (Group 1 and Group 2, Figs. 5a, b, respectively) accordingly to their dung indicative value in the modern dataset. Group 1 includes the most reliable dung indicators with common and abundant types (Sporormiella, Podospora, HdV-55, Trichodelitschia) and occasional ones (Chaetomium, Delitschia, Apiosordaria verruculosa). Group 2 includes all the other spore-types with no or unclear dung affinities.

Application of the modern NPP dataset to the interpretation of the fossil record from Sourzay

The fungal assemblages identified in the modern dataset are mainly related to terrestrial vegetation communities from a pasture-woodland landscape, where modern-day land-uses are characterized by the seasonal presence of relatively diverse livestock (sheep, horses, cows and rarely pigs). The aim is to assess whether such results are 
Table 3 Description of pollen and NPP assemblages from the peat record from Sourzay

\begin{tabular}{llll}
\hline $\begin{array}{l}\text { NPPAZ } \\
\text { Depth } \\
(\mathrm{cm})\end{array}$ & Ages cal A.D. & Pollen \\
\hline 1 & $53-38$ & ca. 175-1280 & $\begin{array}{c}\text { AP/T }<50 \% ; \text { Fagus dominates among trees (ca. } \\
10-15 \%) ; \text { Quercus and Corylus are at constant } \\
\end{array}$ \\
& & $\begin{array}{l}\text { values. Abies increases. Sphagnum, Apiaceae and } \\
\text { Cyperaceae are well represented }\end{array}$
\end{tabular}
38-30 ca. $1280-1510$

$3 a$ $30-26$ ca. $1510-1590$
AP/T still $<50 \%$. Higher proportions of Fagus (ca. 20\%) Juniperus and LPPI slightly increase. Sphagnum decreases and Cyperaceae show their highest values. At the boundary zone 2/3a: sharp increase of Fagus, decrease of Apiaceae and Cyperaceae

$\mathrm{AP} / \mathrm{T}$ is $>55 \%$ when Fagus reaches its highest values (>ca. 30\%) in spectra 29. It then declines significantly; Abies increases. Apiaceae, Cyperaceae and Sphagnum are at lower values. RHAPI, LPPI, Juniperus and Cyperaceae increase at the end of the zone

Poaceae reach $20 \%$ and $\mathrm{AP} / \mathrm{T}$ is around $50 \%$. Corylus decreases. Ericaceae, Calluna, Erica tetralix type and Pteridium are well represented. Higher values of LPPI and RHAPI; both decline slightly in spectra $23 \mathrm{~cm}$ while Fagus and Poaceae increase

$\mathrm{AP} / \mathrm{T}>55 \%$. Fagus, Abies and Quercus increase; Poaceae decline to $10-15 \%$. LPPI fall to their lowest values; RHAPI are constant. Best representation of Ericaceae; Calluna, Juniperus and Pteridium are well represented. Cyperaceae still show constant values (ca. 15\%)

AP/T remains constant (ca. 55\%); LPPI increase (ca. 5\%). Constant values of Quercus. Fagus, LPPI, Calluna, Pteridium and Cyperaceae decrease at the end of the zone while RHAPI increase

AP/T still approx. 55\% with constant values of Quercus. Lower values of Fagus which decline in spectra $5 \mathrm{~cm}$ while LPPI increase. RHAPI are at lower and constant values. Poaceae slightly increase. Ericaceae and Calluna are at lower values while E. tetralix type increases
NPPs

Animal hairs and Acari remains dominate. Few fungal remains except Glomus and HdV-495; rare spores of TM-B, HdV-18, HdV-16 and dungrelated fungi. Few Zygnemataceae and Copepoda spermatophores. Unknown microfossil TM-I and slightly more coprophilous fungi registered at the end of the zone

More fungal spores, especially coprophilous fungi of Group 1 (10-20\%). All the dung-related taxa are well represented; Sporormiella and Sordaria dominate. Glomus, HdV-18, Clasterosporium caricinum, Ustulina deusta, TM-108, TM-N, unknown microfossil TM-I and Rhabdocoela cocoons occur regularly

Coprophilous fungi (10 types), except Apiosordaria verruculosa, decrease in spectra $29 \mathrm{~cm}$ (Group 1 $<5 \%)$. First occurrences of Entophlyctis lobata. Sporormiella, Sordaria, HdV-55B, HdV-18 and C. caricinum increase at the end of the zone while TM-108, TM-N and TM-O decline

C. caricinum decreases; HdV-18 and coprophilous fungi (9 types) increase. Sporormiella, Sordaria, HdV-55B and Podospora (HdV-368 and TM-110) are relatively well represented. All these taxa decrease at the boundary zone $3 / 4$ while Copepoda spermatophores and E. lobata increase

Lowest values of coprophilous fungi (except zone 1) (2-5\%; 8 types). First occurrences of Coniochaeta B. Highest values of HdV-18 (ca. 40\%) late zone. At the boundary zone $4 / 5$ coprophilous fungi (both Groups) increase, HdV-18 decreases abruptly, $U$. deusta, Xylariaceous ascospores and E. lobata slightly decline

Higher values (ca. 10\%) of dung-related Ascomycetes (12 types: 8 types of Group 1; 4 of Group 2). HdV-18 decreases to very low values. Presence of HdV-16, TM-O and Cirrenalia sp., Rhabdocoela and Copepoda decline

Total coprophilous fungi increases importantly $(>20 \%)$. Sporormiella and Sordaria are the most abundant; other types of Group 1 are absent or show low values. Coniochaeta B disappears. Low values of HdV-18. Sharp increase of TM-O and Helicoon and slight increase of Xylariaceous ascospores, $U$. deusta, Cirrenalia sp., and E. lobata in the upper part of the core applicable and useful to the interpretation of the peat fossil record from Sourzay. The two groups of coprophilous fungi (Groups 1 and 2) are used to infer past local pastoral activities and are compared to previous pollen results from the same fossil record (Mazier et al. 2009). Fossil pollen assemblages from this small peat bog ( $\leq 2 \mathrm{ha}$ ) are assumed to have a small pollen source area (Jacobson and Bradshaw 1981; Sugita 1993, 1994) and to provide local reconstruction of past vegetation composition and dynamics. Two distinct groups of pollen indicators have been previously identified by Mazier et al. (2006, 2009) to assess past human activities. The 'Local Pastoral Pollen Indicators' (LPPI), and the 'Regional Human Activities Pollen Indicators' (RHAPI) can be used to infer past local pastoral activities and background human activities, respectively. 
ca. A.D. 175-1280 (NPPAZ 1)

This zone is difficult to interpret due to very low findings of NPPs (Fig. 6; Table 3). On one hand, the pollen data suggests relatively wet local conditions (Sphagnum, Apiaceae, Cyperaceae, Scabiosa) which may have limited both the local development of fungi and the frequentation of the site by animals (therefore no dung may have been deposited). Water accumulation is not possible on this sloping mire but runoff may have occurred. This latter hypothesis seems to be supported by the presence of the exogenous Glomus chlamydospores. On the other hand, the high values of resistant remains of Acari and animal hairs (including Acari hairs as well), could reflect the higher accumulation rate of sediment (ca. $78 \mathrm{yrs} \mathrm{cm}^{-1}$ ) and reveal bad and/or selective preservation of other material. It is unclear as to whether sedimentation conditions (affecting NPP preservation) or local hydrological conditions (inhibiting local fungal growth) are responsible for low NPP findings. Therefore the interpretation of this zone should be considered with caution.

\section{ca. A.D. 1280-1510 (NPPAZ 2)}

It would appear that sedimentation conditions (drier conditions indicated by a decrease in pollen percentages of Sphagnum and an increase in Cyperaceae) provided better local production and/or preservation of fungal remains. The increase of Clasterosporium caricinum (Pals et al. 1980) at the end of the zone confirms the local presence of Cyperaceae (i.e. Carex sp.) on the bog. Mazier et al. (2009) interpreted this period as a phase of both forest expansion (Fagus and Abies) and of an increase in local grazing activities, confirmed by high values of dung-related Ascomycetes (highest values in the profile), particularly those of Group 1 . The increase of Ustulina deusta could be related to the expansion of Fagus. However, as the spores were sometimes found far away from beech forests in the modern dataset, the presence of $U$. deusta in terms of distance from the trees to the peat bog should be interpreted with caution. Apart from low values of Xylariaceous ascospores undiff., no indicator of wooded environments (identified in the modern dataset) was registered. Whether Cercophora, Coniochaeta A or C. cf. ligniaria, well related to beech forests in the modern dataset, are favoured with forest expansion or with an increase in local grazing activities remains an open question.

ca. A.D. $1510-1740$ (NPPAZ 3)

Around ca. A.D. 1530 (spectra 29), the simultaneous decrease in coprophilous fungi (except A. verruculosa) and in LPPI indicates a decline in local grazing activities followed by a forest expansion (Fagus and Abies; Fig. 6), while human activities increase regionally (increase of RHAPI). Because of changes in land-use management, the small basin may have been temporally isolated from the remaining grazing areas (Artxilondo, Occable, Fig. 1; Mazier et al. 2009). The period ca. A.D. $1550-1740$ is characterized by a recovery of both local pastoral and regional human activities (increase in LPPI, coprophilous fungi and RHAPI). A slight decrease in both local and regional human activities is observed in the second half of the 17th century (decrease of Sporormiella, LPPI, RHAPI and increase in Fagus). However, Podospora, Sordaria and HdV-55, well represented for this period, suggest that the livestock may have frequented the surroundings of the bog, most probably less intensively than earlier. Other fungal types suggest changes in bog conditions during the subzone 3b. The ratio between HdV-18 (van Geel 1978) and Clasterosporium caricinum may indicate a local increase in Eriophorum included in the pollen type Cyperaceae.

ca. A.D. 1740-1850 (NPPAZ 4)

High values of HdV-18 may indicate Eriophorum still growing on the peat bog. Low values of coprophilous fungi compared to the former periods show an important decrease in grazing activities in the vicinity of the peat bog at the beginning of the 19th century, in accordance with pollen data. Mazier et al. (2009) argued for the abandonment of the basin as a grazing area (decrease in LPPI) allowing an expansion of forest cover (Fagus and Abies). The presence of Coniochaeta B during this period of lowest grazing pressure concurs with its unclear coprophilous affinity in the modern dataset. Furthermore, the type seems to be associated with an increase in Ericaceae and high values of Calluna (Fig. 6). This leads to the confirmation of the type having either no particular coprophilous affinity or a probable habitat preference, e.g. for heathland.

ca. A.D. 1850-1990 (NPPAZ 5)

The presence of Coniochaeta $\mathrm{B}$ in sub-zone 5a and its absence in sub-zone $5 \mathrm{~b}$ leads to the confirmation of a possible association with Ericaceae (this is lower in subzone 5b, Fig. 6). The increase in coprophilous types suggests an intensification of pastoral activities on the peat bog from the end of the 19th century, as also indicated by the pollen data (increase in LPPI). However, as in zone 3b, Group 1 types are less frequent and less abundant than those found in zone 2 (where almost all dung-related types are recorded). It is possible to attribute these changes in richness and proportions within coprophilous assemblages to changes in density of grazers. However the type of dung 
(Lundqvist 1972; Richardson 1972) and therefore livestock species, or local environmental conditions (e.g. temperature, humidity, vegetation cover; cf. Nyberg and Persson 2002) can affect coprophilous mycobiota and thus also account for such discrepancies.

Potential and limits of the modern NPP dataset as an aid to the interpretation of fossil NPP data

The modern dataset provided valuable information on the relationships between airborne fungal spore-types, vegetation types and grazing pressure regimes. Although informative, our modern approach using moss polsters, principally collected within terrestrial vegetation types (initially for the study of modern pollen rain (Mazier et al. 2006)), may be limited in establishing accurate NPP analogues for the interpretation of a peat record (Prager et al. 2006). This is partially confirmed by our results as (1) several modern fungal and zoological remains were specific to mire vegetation sites (Fig. 3) and (2), except dungrelated Ascomycetes, relatively few modern NPPs were found as fossils (Fig. 6). However, NPPs were poorly represented from ca. A.D. 200 to 1300 (zone 1) and the 700year range for the fossil NPP record may not be long enough to come to such conclusions.

The results also lead to some considerations on the spatial resolution of fungal spores. The presence of spores specific to vegetation communities (e.g. beech forests) in other distant sites (e.g. grasslands) can be explained either by the ecological amplitudes of the fungi which may grow on different vegetation types due to common suitable microhabitat conditions (moisture, light, host plants, decaying substrates etc.), or by the patchiness of the hilly landscape where the NPP assemblages, stemming from a $100 \mathrm{~m}^{2}$ quadrat, may be influenced by adjacent vegetation communities. In the latter case, the spores trapped in the moss polsters can originate either from wind/water transport or from fungi associated to substrates (e.g. fallen branches, twigs or leaves) transported from forests to open sites. Ustulina deusta finds illustrate well the phenomenon of spore transport. Van Geel and Andersen (1988) showed that spores of this parasite found on deciduous trees are not as easily dispersed as pollen grains and that the distance between the sampling site and the forest greatly influences the frequency of the records of the spores. In the modern dataset, the ascospores found in sites located $>100 \mathrm{~m}$ away from the beech forests probably originate from 'long-distance' transport either by wind or water. It was therefore difficult to interpret the occurrences of $U$. deusta in the peat record in terms of distance from the trees (Fagus) to the bog. These elements suggest that the spatial indicative value of some fungal remains is not fully understood and that further modern approaches could be improved in this respect. These considerations are particularly important for palaeoecological studies using NPPs from small peat bogs, as is often the case in highland regions.

Based on the modern dataset, the complete spectrum of dung-related Ascomycetes, including types with differing dung affinities, is correlated to grazing pressure. This concurs with the idea of van Geel et al. (2007) and has been used by Mazier et al. (2009) to confirm the validity of the pastoral pollen indicators they identified on the basis of modern pollen/vegetation relationships in the area. The complete spectrum of coprophilous spores reveals three main phases of high grazing pressure which alternate with two phases of decrease/abandonment of pastoral activities in the basin (ca. A.D. 1500-1550 and ca. A.D. 1750-1830, Fig. 6). Those phases may be related to the so-called 'Little Ice Age' period (LIA) which was locally assessed as being from ca. A.D. 1560 to 1840 by dendrochronological measurements (Bourquin-Mignot and Girardclos 2001). However, historical sources show that population and human activities increased significantly in the Basque Mountains at the beginning of the 16th century (Goyhenetche 2001; Legaz 2005). The second phase of decline might be related to troubles over border demarcation between France and Spain and/or to the competition between pastoral and forest activities (Brocas and Legaz 2005). There is no obvious relation between the LIA and the decline of pastoral activities in the Sourzay basin although the LIA cooling event may have had limited effects on summer pastoral activities in these middle-altitude areas $(<1,500 \mathrm{~m}$ a.s.1).

As in the modern dataset, Sporormiella, Sordaria, HdV55B and Podospora were the most abundant through the entire profile (except in zone 1) and showed similar patterns (especially Sporormiella and Sordaria). The trends of fossil spore-types of Group 2 associated to beech forests in the modern dataset (Cercophora, Coniochaeta cf. ligniaria, Coniochaeta A, Gelasinospora), were more difficult to interpret since forest (expansion/regression) and pastoral activity (increase/decrease) dynamics occurred over short periods. Nevertheless, as these types were not abundant, their inclusion in the total coprophilous sum did not significantly affect the trend of the main coprophilous signal (Mazier et al. 2009). The modern Cercophora spore-type has been shown as a good dung indicator with other coprophilous types in woodland environments (Blackford and Innes 2006) and grasslands (Graf and Chmura 2006). The fossil type has often been reported as a dung indicator (e.g. van Geel et al. 1983; Ralska-Jasiewisczowa and van Geel 1992; Innes and Blackford 2003; van Geel et al. 2003; Blackford et al. 2006). In the record from Sourzay, Cercophora had contradictory trends to those of types of Group 1 (Fig. 6). However, such comparisons between records may be unsuccessful considering the different 
species included in the Cercophora spore-type (van Geel and Aptroot 2006) which may vary in their ecological demands (e.g. Krug et al. 2004). Therefore, the extension of our modern dataset to grazed forests is necessary in order to asses whether more precise indicative values can be derived from such saprobe fungal types. It is also evident that this will greatly depend on the level of identification and on the nomenclature adopted.

The coprophilous assemblages linked to modern-day environments and land-uses in the Iraty mountains provide a robust tool for reconstructing grazing pressure variations over the last ca. 700 years (since NPPs are poorly represented before then) in the Sourzay basin. However, this must be put into perspective considering the time span of pastoral activities that may have existed in the area. Pollen data provide evidence for an open landscape with pastoral activities since ca. 130 B.c. (Mazier et al. 2009). Human occupation has been attested in the study area since MidNeolithic times (Mikelauen-Zilo cave, Marembert 2000) and grazing activities have been testified by dated shepherds' huts and enclosures situated on the mountain crest (Occabe, Fig. 1) since at least the late Bronze Age (Galop et al. 2004; Carozza et al. 2005). It can be concluded that such coprophilous assemblages are relevant for periods of a long-term pastoral history.

\section{Conclusions}

The main conclusions of this paper are:

(1) The study of modern moss samples from terrestrial environments provides useful information on the relationship between NPPs (mainly airborne fungal spores) and vegetation types within a mountainous pasture-woodland landscape. However, such an approach needs to be extended to different wetland ecosystems in order to supply more reliable NPP analogues for the interpretation of peat records. The spatial indicative value of some fungal remains (e.g. dispersal and transport of spores) also appears as a possible research field, especially in the perspective of the study of fossil spectra from small peat deposits $(<1$ ha).

(2) The modern approach shows different dung indicative values among the thirteen dung-related Ascomycetes sporetypes. The most reliable dung indicators include common and abundant types (Sporormiella, Podospora, HdV-55 and probably Trichodelitschia) and less frequent ones (Chaetomium, Delitschia, Apiosordaria verruculosa). Dung affinities of other spore-types (Cercophora, Coniochaeta A-B, Coniochaeta cf. ligniaria, Gelasinospora) are less obvious as they may have affiliations with other decaying substrates rather than dung or have particular habitat preferences.

(3) These coprophilous assemblages identified in modern-day environments and for current land-uses are very valuable indicators of historical pastoral dynamics in the Basque mountains, a territory with a long pastoral history. It is now necessary to ascertain whether and how such coprophilous assemblages can be used for earlier periods in order to assess first signs of grazing activities and their evolution through time.

Acknowledgements This study was funded by the PCR "Palaeoenvironment and human activities on the Basque mountain" (Ministry of Culture and SRA Aquitaine) and ATIP-CNRS "Palaeoenvironment and Pastoral Archaeology" programs headed by D. Galop. We are very grateful to Bas van Geel and André Aptroot for assistance with identifying NPPs and fungal spores, to Nicolas de Munnik for constructive comments and for having given access to his mycological library, to Mike Richardson for advice on coprophilous fungi ecology and to Sophie Chambers for having revised the English. The authors would like to thank Jean Nicolas Haas and two anonymous referees for their helpful comments and suggestions on the manuscript.

\section{References}

Aptroot A (2006) Gasteromycetes, a source of fossil spores. Abstracts of the 2nd international workshop on non-pollen palynomorphs. Palyno-Bulletin 2:12

Aptroot A, van Geel B (2006) Fungi of the colon of the Yukagir Mammoth and from stratigraphically related permafrost samples. Rev Palaeobot Palynol 141:225-230

Bell A (2005) An illustrated guide to the coprophilous Ascomycetes of Australia. Utrecht, The Netherlands

Blackford J, Innes J (2006) Linking current environments and processes to fungal spore assemblages: surface NPM data from woodland environments. Rev Palaeobot Palynol 141: $179-187$

Blackford J, Innes J, Hatton J, Caseldine C (2006) Mid-Holocene environmental change at Black Ridge Brook, Dartmoor, SW England: a new appraisal based on fungal spore analysis. Rev Palaeobot Palynol 141:189-201

Bos J, van Geel B, Groenewoudt B, Lauwerier R (2005) Early Holocene environmental change, the presence and disappearance of early Mesolithic habitation near Zutphen (The Netherlands). Veget Hist Archaeobot 15:27-43

Bourquin-Mignot C, Girardclos O (2001) Construction d'une longue chronologie de hêtres au Pays Basque. La forêt d'Iraty et le Petit Âge Glaciaire. Sud-Ouest Européen 11:59-71

Boyd W (1986) The role of mosses in modern pollen analysis: the influence of moss morphology on pollen entrapment. Poll Spores 28:243-255

Brocas D, Legaz A (2005) La montagne basque: sources et ressources. Les pâturages et les bois dans les Pyrénées occidentales (XIe-XIXe siècles). Congrès international RESOPYR, Presses Universitaires de Perpignan, Perpignan

Burney D, Robinson G, Pigott Burney L (2003) Sporormiella and the late Holocene extinctions in Madagascar. PNAS 100:1080010805

Carozza L, Galop D, Marembert F, Monna F (2005) Quel statut pour les espaces de montagne durant l'âge du Bronze? Regards croisés sur les approches sociétés-environnement dans les Pyrénées occidentales. Doc Archéo Mérid 28:7-23

Cooke R, Rayner A (1984) Ecology of saprotrophic fungi. New York

Davis OK (1987) Spores of the dung fungus Sporormiella: increased abundance in historic sediments and before Pleistocene megafaunal extinction. Quatern Res 28:290-294 
Davis OK, Shafer DS (2006) Sporormiella fungal spores, a palynological means of detecting herbivore density. Palaeogeogr Palaeoclim Palaeoecol 237:40-50

Decisia (2002) Spad rel. 5.5: Système pour l'analyse des données. Levallois-Perret, France

Ebersohn C, Eicker A (1992) Trichodelitschia microspora, a new coprophilous species from South Africa. S Afr J Bot 58:145-146

Ellis M (1971) Dematiaceous hyphomycetes. UK

Ellis M, Ellis J (1985) Microfungi on land plants. An identification handbook. Croom Helm, London and Sydney

Ellis M, Ellis J (1998) Microfungi on miscellaneous substrates. An identification handbook. New enlarged edition, The Richmond Publisher, England

Faegri K, Iversen J (1989) Textbook of pollen analysis, 4th edn, revised by Faegri K, Kaland PE and Krzywinski K. Wiley, Chichester

Galop D, Rendu C, Barcet H, Buttler A, Campmajo P, Cugny C, Gauthier E, Legaz A, Lopez-Saez J-A, Mazier F, Métailié J-P, Sordoillet D, Vannière B (2004) Paléoenvironement et archéologie pastorale. Propositions méthodologiques pour une approche intégrée des modalités de l'anthropisation en haute montagne pyrénéenne du Néolithique à l'actuel. Besançon

Goyhenetche M (2001) Histoire générale du Pays Basque (Tome III) Evolution économique et sociale du $\mathrm{XVI}^{\mathrm{e}}$ au $\mathrm{XVIII}^{\mathrm{e}}$ siècle. Elkarlanean, Donostia

Graf M-T, Chmura G (2006) Development of modern analogues for natural, mowed and grazed grasslands using pollen assemblages and coprophilous fungi. Rev Palaeobot Palynol 141:139-149

Hausmann S, Lotter A, van Leeuwen J, Ohlendorf C, Lemcke G, Grönlund E, Sturm M (2002) Interactions of climate and land use documented in the varved sediments of Seebergsee in the Swiss Alps. Holocene 12:279-289

Innes J, Blackford J (2003) The ecology of Late Mesolithic woodland disturbances: model testing with fungal spore assemblage data. J Archaeol Sci 30:185-194

Jacobson G, Bradshaw R (1981) The selection of sites for paleovegetational studies. Quatern Res 16:80-96

Kiffer E, Morelet M (1997) Les Deutéromycètes. Classification et clés d'identification générique, INRA éditions, Paris

Krug JC, Benny GL, Keller HW (2004) Coprophilous fungi. In: Mueller GM (ed) Biodiversity of fungi. Academic Press, Burlington, pp 467-499

Legaz A (2005) Systèmes pastoraux et sociétés en Basse Navarre du XIII au XVIII siècles: construction et transitions. PhD thesis, Université Toulouse-Le Mirail, Toulouse

Lundqvist N (1972) Nordic Sordariaceae s. lat. Symb Bot Upsal 20: $1-374$

Marembert F (2000) La grotte de Mikelauen-Zilo. In: Galop D (ed) Paléoenvironnement et dynamiques de l'anthropisation en Montagne Basque. Internal report PCR, SRA Aquitaine, CNRS, Toulouse, pp 71-87

Mazier F, Galop D, Brun C, Buttler A (2006) Modern pollen assemblages from grazed vegetation in the western Pyrenees, France: a numerical tool for more precise reconstruction of past cultural landscapes. Holocene 16:91-103

Mazier F, Galop D, Gaillard M-J, Rendu C, Cugny C, Legaz A, Peyron O, Buttler A (2009) Multidisciplinary approach to reconstruct pastoral activities. An example from the Pyrenean Mountains (Pays Basque). Holocene 19:171-178

Mighall T, Martinez Cortizas A, Biester H, Turner SE (2006) Proxy climate and vegetation changes during the last five millennia in NW Iberia: pollen and non-pollen palynomorph data from two ombrotrophic peat bogs in the North Western Iberian Peninsula. Rev Palaeobot Palynol 141:203-223

Moore P, Webb J, Collinson M (1991) Pollen analysis, 2nd edn, Oxford
Mulder C, Beure A, Joosten J (2003) Fungal functional diversity inferred along Ellenberg's abiotic gradients: palynological evidence from different soil microbiota. Grana 42:55-64

Mulder C, Janssen C (1999) Occurence of pollen and spore in relation to present-day vegetation in a Dutch heathland area. J Veg Sci 10:87-100

Nyberg A, Persson I-L (2002) Habitat difference of coprophilous fungi on moose dung. Mycol Res 106:1360-1366

Pals J, van Geel B, Delfos A (1980) Palaeoecological studies in the Klokkeweel bog near Hoogkarspel (prov of Noor Holland). Rev Palaeobot Palynol 30:371-418

Prager A, Barthelmes A, Theuerkauf M, Joosten H (2006) Non-pollen palynomorphs from modern Alder carrs and their potential for interpreting microfossil data from peat. Rev Palaeobot Palynol 141:7-31

Ralska-Jasiewisczowa M, van Geel B (1992) Early Human disturbance of natural environment recorded in annually laminated sediments of Lake Gosciaz, central Poland. Veget Hist Archaeobot 1:33-42

Reille M (1992-1998) Pollen et spores d'Europe et d'Afrique du Nord. Marseille

Reimer P, Baillie M, Bard E, Bayliss A, Beck J, Bertrand C, Blackwell P, Buck C, Burr G, Cutler K, Damon P, Edwards R, Fairbanks R, Friedrich M, Guilderson T, Hogg A, Hughen K, Kromer B, McCormac G, Manning S, Ramsey C, Reimer R, Remmele S, Southon J, Stuiver M, Talamo S, Taylor F, van der Plicht J, Weyhenmeyer C (2004) IntCal04 terrestrial radiocarbon age calibration, 0-26 cal Kyr B.P. Radiocarbon 46:1029-1058

Richardson J, Walting R (1982) Keys to fungi on dung, revised edn. The British Mycological Society

Richardson M (1972) Coprophilous Ascomycetes on different dung types. Trans Br Mycol Soc 58:37-48

Stuiver M, Reimer P (1993) Extended 14C data base and revised CALIB 3.0 14C age calibration program. Radiocarbon 35:215-230

Sugita S (1993) A model of pollen source area for an entire lake surface. Quatern Res 39:239-244

Sugita S (1994) Pollen representation of vegetation in Quaternary sediments: theory and method in patchy vegetation. J Ecol $82: 881-897$

van Geel B (1978) A palaeoecological study of Holocene peat bog sections in Germany and The Netherlands, based on the analysis of pollen, spores and macro- and microscopic remains of fungi, algae, cormophytes and animals. Rev Palaeobot Palynol 25:1-120

van Geel B (2001) Non-pollen palynomorphs. In: Smol J, Birks HJB, Last W (eds) Tracking environmental change using lake sediments. Vol 3: Terrestrial, algal, and silicaceous indicators. Kluwer, Dordrecht, pp 99-109

van Geel B, Andersen ST (1988) Fossil ascospores of the parasitic fungus Ustulina deusta in Eemian deposits in Danmark. Rev Palaeobot Palynol 56:89-93

van Geel B, Aptroot A (2006) Fossil ascomycetes in Quaternary deposits. Nova Hedw 82:313-329

van Geel B, Bos J, Pals J (1983) Archaeological and palaeoecological aspects of a medieval house terp in a reclaimed raised bog area in north Holland. Ber Rijksd Oudheidk Bodemonderz 33:419-444

van Geel B, Buurman J, Brinkkemper O, Schelvis J, Aptroot A, van Reenen G, Hakbijl T (2003) Environmental reconstruction of a Roman Period settlement site in Uitgeest (The Netherlands), with special reference to coprophilous fungi. J Archaeol Sci 30:873-883

van Geel B, Zazula G, Schweger C (2007) Spores of coprophilous fungi from under the Dawson tephra $\left(25,300{ }^{14} \mathrm{C}\right.$ years $\left.\mathrm{BP}\right)$, Yukon Territory, northwestern Canada. Palaeogeogr Palaeoclim Palaeoecol 252:481-485

Yeloff D, Charman D, van Geel B, Mauquoy D (2007) Reconstruction of hydrology, vegetation and past climate change in bogs using fungal microfossils. Rev Palaeobot Palynol 146:102-145 